\title{
First Report of Peanut mottle virus in Forage Peanut (Arachis pintoi) in the United States
}

K. K. Dey, ${ }^{\dagger}$ Florida Department of Agriculture and Consumer Services, Division of Plant Industry, Gainesville, 32614; L. Hassell, Florida Department of Agriculture and Consumer Services, Division of Plant and Apiary Industry, Tallahassee, 32399; C. Li, Florida Department of Agriculture and Consumer Services, Division of Plant Industry, Gainesville, 32614; M. Elliott, University of Florida, Gainesville, 32614; and X. Sun, Florida Department of Agriculture and Consumer Services, Division of Plant Industry, Gainesville, 32614

Accepted for publication 15 December 2017.

Arachis pintoi is a perennial peanut species grown in many tropical and subtropical countries around the world such as Australia, Brazil, and Colombia (Palmieri et al. 2010). Because of its high nutritive value and excellent ability to bind eroded soils, $A$. pintoi is increasingly being used both as a forage crop and as a ground cover. It is also increasingly being used as a landscape plant in urban settings. In the United States, A. pintoi is mostly grown in the southern coastal plain regions. Currently, Arachis glabrata is more widely grown in the southern coastal plain, with area more than 10,500 ha (Nischwitz et al. 2007). Although Peanut mottle virus (PeMoV) was reported in A. glabrata from Georgia in 2007 (Nischwitz et al. 2007), there are no reports of PeMoV infecting $A$. pintoi in the United States. In June 2017, samples of symptomatic A. pinto $i$ were taken from a retail garden center in Nassau County, FL, by a Florida Department of Agriculture and Consumer Services Division of Plant Industry (FDACS-DPI) inspector. The $A$. pintoi plants originated from Hardee County, FL. Samples of A. pintoi and A. glabrata were also collected by FDACS-DPI from the Hardee County propagator and submitted to the Division of Plant Industry in Gainesville, FL. The leaves of the plants showed a variety of symptoms ranging from yellowing to dark islands, green vein banding, and mild mottling (Fig. 1). Symptomatic leaves were tested for Peanut stunt virus (PSV) using double antibody sandwich ELISA (Agdia, Elkhart, IN) and for potyvirus using a broad-spectrum lateral flow antibody immunoassay (Agdia). PSV was not detected, but all samples tested positive for potyvirus. To identify the potyvirus, RNA was extracted from four positive samples using an RNeasy Plant Mini kit (Qiagen, Valencia, CA). One-step reverse-transcription (RT)-PCR (Qiagen) was performed using the degenerate potyvirus forward primer, Sprimer (5'-GGNAAYAAYAGYGGNCARCC-3') (Chen et al. 2001) or CpUP (5'-TGAGGATCCTGGTGYATHGARAAYGG-3') (van der Vlugt et al. 1999) and the reverse primer M4T (5'-GTTTT CCCAGTCACGAC $(\mathrm{T}) 15^{-3^{\prime}}$ ) (Chen et al. 2001), which target the $3^{\prime}$ terminal region of most potyviruses. The temperature cycling parameter of the RT-PCR consisted of a reverse-transcription reaction at $50^{\circ} \mathrm{C}$ for $30 \mathrm{~min}$, enzyme inactivation at $95^{\circ} \mathrm{C}$ for $15 \mathrm{~min}$ followed by 35 cycles of $94^{\circ} \mathrm{C}$ for $30 \mathrm{~s}, 51^{\circ} \mathrm{C}$ for $60 \mathrm{~s}$, and $72^{\circ} \mathrm{C}$ for $60 \mathrm{~s}$, and a final extension of $72^{\circ} \mathrm{C}$ for $5 \mathrm{~min}$. No amplification was observed for the CpUP and M4T primer combination, but Sprimer and M4T produced an amplicon of the expected size ( $\sim 700 \mathrm{bp})$. This product was cloned using pGEM-T Easy

${ }^{\dagger}$ Corresponding author: K. K. Dey; E-mail: kishore.dey@freshfromflorida.com

Funding was provided by the Florida Department of Agriculture and Consumer Services (concept ID 10.13039/100011508).

(C) 2018 The American Phytopathological Society

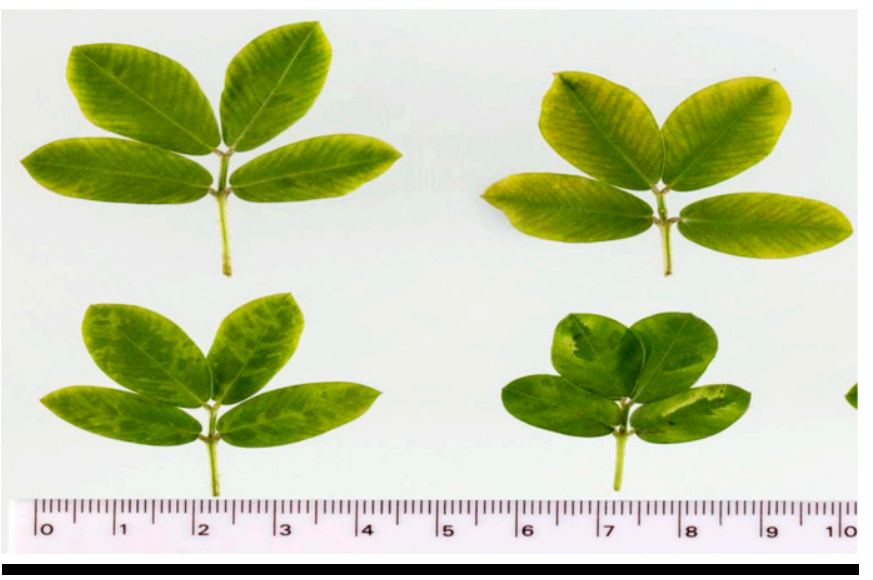

FIGURE 1

Symptoms of Peanut mottle virus infection of Arachis pintoi in Florida. Individual leaves with yellowing to dark islands, green vein banding, and mild mottling.

II (Promega, Madison, WI), and four clones were sequenced in both directions (GenBank accession no. MF990885). A BLASTN search against the GenBank database indicated the cloned sequences had $99 \%$ identity with PeMoV (GenBank accession no. AF023848.1). Additional confirmation was done for all the samples with primers specific for PeMoV (Nischwitz et al. 2007) (GCTGTGAATTGTTGTTGA GAA/ACAATGATGAAGTTCGTTAC, amplicon size = 327). Detection of PeMoV in A. pintoi is significant because it is transmitted by aphids in a nonpersistent manner and is seed-borne in A. hypogea (Adams and Kuhn 1977). It is not known if PeMoV is seed-borne in A. pintoi. However, A. pintoi is commonly vegetatively propagated using stolon cuttings. It is possible that $\mathrm{PeMoV}$ can spread to $A$. pintoi in Florida by all these means, making maintenance of virus-free propagation stock plants important. To our knowledge, this is the first report of PeMoV in A. pintoi in Florida, United States.

\section{Acknowledgment}

The authors thank the Department of Plant Industry (DPI), Florida Department of Agriculture and Consumer Services (FDACS), for all assistance with the project.

\section{Literature Cited}

Adams, D. B., and Kuhn, C. W. 1977. Seed transmission of Peanut mottle virus in peanuts. Phytopathology 67:1126-1129.

Chen, J., Chen, J., and Adams, M. J. 2001. A universal PCR primer to detect members of the Potyviridae and its use to examine the 
taxonomic status of several members of the family. Arch. Virol. 146: 757-766.

Nischwitz, C., Maas, A. L., Mullis, S. W., Culbreath, A. K., and Gitaitis, R. D. 2007. First report of Peanut mottle virus in forage peanut (Arachis glabrata) in North America. Plant Dis. 91:632.

Palmieri, D. A., Bechara, M. D., Curi, R. A., Monteiro, J. P., Valente, S. E. S., Gimenes, M. A., and Lopes, C. R. 2010. Genetic diversity analysis in the section Caulorrhizae (genus Arachis) using microsatellite markers. Genet. Mol. Biol. 33:109-118.

van der Vlugt, R. A. A., Steffens, P., Cuperus, C., Barg, E., Lesemann, D.-E., Bos, L., and Vetten, H. J. 1999. Further evidence that Shallot yellow stripe virus (SYSV) is a distinct potyvirus and reidentification of Welsh onion yellow stripe virus as a SYSV strain. Phytopathology 89: 148-155. 